\title{
The Analysis of Halal Assurance System Implementation (HAS 23000) in Fried chicken Flour Product: A Case Study on XXX Brand
}

\author{
Nunuk Adiarni ${ }^{\mathbf{a}^{*}}$ Anisaa Fortunella ${ }^{\mathrm{b}}$ \\ ${ }^{\mathrm{a}, \mathrm{b}}$ Department of Agribusiness, \\ Faculty of Science and Technology, State Islamic University Syarif Hidayatullah \\ South Tangerang, Indonesia \\ *Email: adiarnisunarjo@gmail.com,nunukadiarni@uinjkt.ac.id
}

\begin{abstract}
The number of halal certified products as recorded by the Directorate Generale of Islamic Religious Community guidance reached $60.76 \%$ of the total product in circulation. Muslim consumers with $85 \%$ of the total population of Indonesia required halal food guarantee. The order of eating in the Holy Al Qur'an addressed as many as 28 times. One of them is in the Surah Abasa verses 24. Fried chicken flour products are included in the category of critical products based on raw material used in production. This study aims to analyze the consistency and appropriateness of the implementation of halal assurance system by HAS 23000 version. The study covered on production department, logistic, warehouse and three selected outlets Ciputat, Legoso and Pondok Ranji. Gap analysis and consistency were derived from eleven criteria as stated in HAS 23000, and 39 indicators developed. There are six ranges in the gap analysis with $0-5 \%$ assessed as A because the application and the halal document have been zero risk and $61-80 \%$ status $\mathrm{C}$ because not all activities are run, and inconsistent. The results showed an average gap of $15 \%$ on corporate resources that have not been optimal. In details as follows; level of gap in Halal policy criteria; 7\%, management team $40 \%$, training and education, $20 \%$, materials $10 \%$, production facilities $6 \%$, written procedure in crucial activities $16 \%$ and management review $45 \%$. In addition, level of consistency of application of work instruction obtained in logistics and stockiest at level 85,08\%, outlet equal to $82,53 \%$, and production $78,34 \%$.
\end{abstract}

Keywords: HAS 23000, Consistency, Conformity

\section{Introduction}

Food is needed by human for the sustainability of life and as a value of worship in the perspective of Islam. There is word akala as stated in the Holy Al Qur'an which means literally "Eat" but not merely taking something through the throat, it is an activity as written in Surah an Nahl verse 114 :"So eat of the lawful (halaalan) and good food (thayyiban) which Allah has provided for you and be grateful for the favor of Allah, if it is He Whom you worship [1].
The requirement of halal and haram for food, medicines and cosmetics are [32];1) food and beverage is good, that is tasty by the senses, not causing sick and not disgusting, 2) not containing hazard ingredients for human (dhahar), 3) does not contain any filth that preclude the validity of shalat (prayer in Islam), and 4) not intoxicating [34]. There are 28 of order to eat written on the Holy Al Qur'an. Surah Al Maidah verse 3 explains Allah's command of the haram food [1].

The Halal food is very important for Moslem which around $85 \%$ of 255 million population in Indonesia [5]. Indonesia on the other hand becomes a very attractive market for halal food. The Directorate General of Islamic Community Guidance of the Ministry of Religious Affairs stated that the number of halal certified products up to 2014 is 53,383 compared to those distributed according to BPOM of 231,851 products.

The assurance of halal products is done through LPPOM MUI certification using evaluation guidance of Halal Assurance System HAS 23000 [14,15]. The HAS 23000 is a requirement document for certification issued by LPPOM MUI. This HAS 23000 must be consistently implemented by food product processor in order to get halal certificate. PT SDM as an object of this study produced flour ingredient, to batter fast food of fried chicken product XXX brand distributed to 124 outlets in Jakarta, Bogor, Depok, Tangerang, Bekasi, Bandung, Surabaya and Padang. Fried chicken products are considered critical from the raw material due to the difficulty level of tracing ingredients used, since one of the basic principles of halal certification is traceability [13]. This study therefore formulates the problem as follow :

a. How is the document of Halal asurance system conform to manual HAS 23000

b. How the HAS 23000 implemented according to the manual

c. How is the consistency of HAS 23000 implementation

The company established 11 halal criteria due to more than one critical ingredient used in product that means as risk category [6]. 


\section{Conceptual and Methodology}

Islam is very concerned about food and placing it as an essential need for human life. Moslems are commanded to eat halal and thayyiban as good food product and leave it that is prohibited or haram [20].

The Holy Al Qur'an stated in number of verses that the basis of food prohibition criteria for Haram food is due to the substance itself and how to obtain it as written in; Al Maidah verse 3, Al An'am verse 145, Al Maidah verse 96, Al Baqarah verse 173 [1].

The principle of HAS basically refers to the concept of Total Quality Management that emphasizes on quality control on every stage of production process $[2,11]$. The four basic concepts of the system is a commitment to meet the requirements and expectations of consumers, improve production quality at affordable prices, free of rework, reject and investigations [22]. The important production aspects of HAS are three zero; limit, defect and risk by emphasizing no haram ingredients used, to be assured there is no prohibited products or additional raw material during process $[14,15]$. In addition, it needs commitment from all stakeholders in the organization, starting from the procurement of raw materials to distribution. The HAS is declared as good when all the system requirements are clearly stated in the documentation, carried out consistently in order to achieve the intended objectives. The HAS 23000 is an integrated quality management system with the aim for ensuring halal product continues along the validity period of the certificate.

The HAS 23000 as implemented contains two parts: 1) the certification requirement that includes the system criteria and 2) the requirements of the policies and procedures.

The halal criteria must be written in the manual, covering number of criteria depends on the level of product risk to be certified, divided into no risk, risk and high risk critical level of material and difficulty in traceability.

The contents of HAS manual based on the category of the company's products with 11 criteria included policy, management team, training and education, materials, products, facilities, written procedures of critical activity, handling products that do not fit halal requirements, and management review.

The raw materials used should not contain any ingredients from pork and their derivatives. Food consumed is prohibited to contain intoxicating alcohol or blood. Even, food should not contain haram ingredients nor use the same equipments or facilities used to handle products derived from pork and their derivatives".

The processor should implements the encoding of material which can be assured by traceability and have documents of all materials used, procedure to ensure that the document still valid

Basic principal for halal certification is traceability [13]. The implemented HAS should be able to verify the raw materials used until the product is delivered to the consumer and audit by certified auditor. Scope of the audit conducted is raw material used, facilities, document, and management system as stated in the manual. This study refers to eleven criteria as of the LPPOM MUI standard by comparing critical point to manual. Implementation and system consistency also comparing to manual HAS [15].

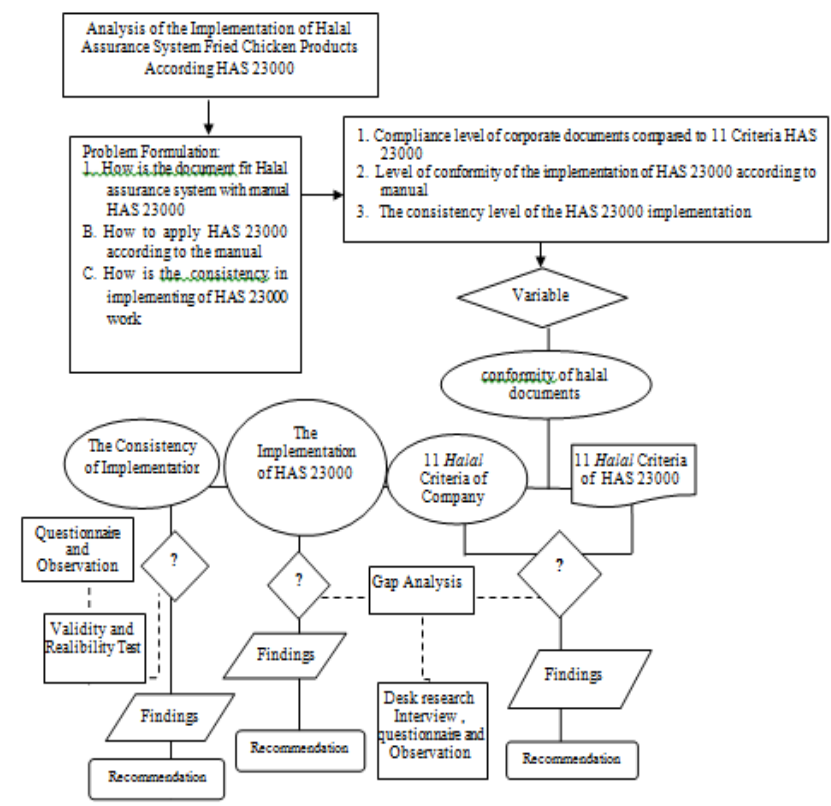

Figure 1. Research Conceptual Framework

This study starts by preliminary survey to describe study problem. Categorization of variable based on 11 criteria as guidance for research, and then comparing implementation and manual as developed by organization [6].

The variables are derived into sub variables and 39 indicators. The instrument validity test is done through content validity test, construct and legibility and reliability test using cronbach alpha $[3,4,21,24,30]$.

Table 1. The definition on operational terms

\begin{tabular}{|c|c|c|}
\hline Variable & Sub. Variabel & Indicator \\
\hline \multirow[t]{5}{*}{ Policy } & Commitment & $\begin{array}{l}\text { Availability of policy } \\
\text { sentence }\end{array}$ \\
\hline & Objective & $\begin{array}{l}\text { Availability of policy } \\
\text { objective }\end{array}$ \\
\hline & Resources & $\begin{array}{l}\text { Availability of } \\
\text { competent resources in } \\
\text { applying the halal } \\
\text { policies of the company }\end{array}$ \\
\hline & \multirow[t]{2}{*}{ Socialization } & Policy distribution \\
\hline & & $\begin{array}{l}\text { Various media } \\
\text { socialization }\end{array}$ \\
\hline \multirow[t]{3}{*}{ Management team } & Organization structure & $\begin{array}{l}\text { Availability of } \\
\text { organization structure }\end{array}$ \\
\hline & Member & $\begin{array}{l}\text { Level of team member } \\
\text { competency in } \\
\text { accordance with HAS } \\
23000\end{array}$ \\
\hline & Performance & $\begin{array}{l}\text { Level of involvement, } \\
\text { responsibility, and } \\
\text { authority of every } \\
\text { function in applying the } \\
\text { system }\end{array}$ \\
\hline
\end{tabular}


Table 1. The definition on operational terms (Cont.)

\begin{tabular}{|c|c|c|}
\hline Variable & Sub. Variabel & Indicator \\
\hline \multirow[t]{5}{*}{$\begin{array}{l}\text { Training and } \\
\text { education }\end{array}$} & Procedure & $\begin{array}{l}\text { Availability of implementation } \\
\text { procedure in training and } \\
\text { education }\end{array}$ \\
\hline & Implementation & $\begin{array}{l}\text { Level of procedure conformity } \\
\text { in training implementation } \\
\text { activities }\end{array}$ \\
\hline & \multirow{2}{*}{$\begin{array}{l}\text { Result of halal } \\
\text { training and } \\
\text { education }\end{array}$} & $\begin{array}{l}\text { Level of employee } \\
\text { understanding in material } \\
\text { training and education }\end{array}$ \\
\hline & & $\begin{array}{l}\text { Evaluation of training and } \\
\text { education }\end{array}$ \\
\hline & Documentation & $\begin{array}{l}\text { Level of documentation } \\
\text { availability }\end{array}$ \\
\hline \multirow[t]{2}{*}{$\begin{array}{l}\text { Raw } \\
\text { Material }\end{array}$} & $\begin{array}{l}\text { Raw material } \\
\text { availability }\end{array}$ & $\begin{array}{l}\text { Procurement of halal raw } \\
\text { materials in accordance } \\
\text { LPPOM MUI provisions }\end{array}$ \\
\hline & Documentation & Availability of documentation \\
\hline \multirow[t]{3}{*}{ Product } & \multirow{3}{*}{ Requirement } & $\begin{array}{l}\text { Conformity product name as } \\
\text { halal guidance }\end{array}$ \\
\hline & & $\begin{array}{l}\text { Conformity of product } \\
\text { characteristic as halal guidance }\end{array}$ \\
\hline & & $\begin{array}{l}\text { Availability of product } \\
\text { description }\end{array}$ \\
\hline \multirow[t]{2}{*}{$\begin{array}{l}\text { Production } \\
\text { facilities }\end{array}$} & Processing & $\begin{array}{l}\text { Facility maintenance in } \\
\text { processing area to prevent from } \\
\text { to prevent from dirty substances }\end{array}$ \\
\hline & Outlet & $\begin{array}{l}\text { Facility maintenance in outlet } \\
\text { area to prevent from dirty } \\
\text { substances or unclean }\end{array}$ \\
\hline \multirow[t]{3}{*}{$\begin{array}{l}\text { Procedure } \\
\text { for critical } \\
\text { activities }\end{array}$} & Procedure & $\begin{array}{l}\text { Availability of procedure for all } \\
\text { critical activity }\end{array}$ \\
\hline & Implementation & $\begin{array}{l}\text { Implementation consistency of } \\
\text { critical activities in accordance } \\
\text { with written procedure }\end{array}$ \\
\hline & Documentation & $\begin{array}{l}\text { Availability of critical activities } \\
\text { implementation documentation }\end{array}$ \\
\hline \multirow[t]{4}{*}{ Traceability } & Procedure & $\begin{array}{l}\text { Availability of material } \\
\text { procedure used in production }\end{array}$ \\
\hline & $\begin{array}{l}\text { Conformity of } \\
\text { information }\end{array}$ & $\begin{array}{l}\text { Level of raw material } \\
\text { information conformity and } \\
\text { traceability }\end{array}$ \\
\hline & Implementation & $\begin{array}{l}\text { Level of implementation and } \\
\text { traceability }\end{array}$ \\
\hline & Documentation & $\begin{array}{l}\text { Availability of implementation } \\
\text { document }\end{array}$ \\
\hline \multirow{3}{*}{$\begin{array}{l}\text { Handling for } \\
\text { out of } \\
\text { Product } \\
\text { quality }\end{array}$} & Procedure & $\begin{array}{l}\text { Availability of Product } \\
\text { handling procedures that not } \\
\text { meet the quality criteria }\end{array}$ \\
\hline & Implementation & $\begin{array}{l}\text { Level of implementation } \\
\text { procedure in handling product } \\
\text { that not meet the quality criteria }\end{array}$ \\
\hline & Dokumentation & $\begin{array}{l}\text { Level of availability in product } \\
\text { handling documentation that } \\
\text { not meet the quality criteria }\end{array}$ \\
\hline
\end{tabular}

\begin{tabular}{|c|c|c|}
\hline \multirow[t]{4}{*}{$\begin{array}{l}\text { Internal } \\
\text { audit }\end{array}$} & $\begin{array}{l}\text { Program } \\
\text { Planning }\end{array}$ & $\begin{array}{l}\text { Level of clarity in audit } \\
\text { planning }\end{array}$ \\
\hline & Procedure & $\begin{array}{l}\text { Level of availability in internal } \\
\text { audit procedure }\end{array}$ \\
\hline & Implementation & $\begin{array}{l}\text { Level of implementation in } \\
\text { internal audit procedure }\end{array}$ \\
\hline & Documentation & $\begin{array}{l}\text { Level of documentation } \\
\text { availability in internal audit } \\
\text { and fully maintained }\end{array}$ \\
\hline \multirow[t]{5}{*}{$\begin{array}{l}\text { Managemen } \\
\mathrm{t} \text { review }\end{array}$} & $\begin{array}{l}\text { Program } \\
\text { planning }\end{array}$ & $\begin{array}{l}\text { Level of clarity in review } \\
\text { planning }\end{array}$ \\
\hline & Procedure & $\begin{array}{l}\text { Level of availability in } \\
\text { management review procedure }\end{array}$ \\
\hline & & $\begin{array}{l}\text { Implementation of review } \\
\text { procedure }\end{array}$ \\
\hline & & $\begin{array}{l}\text { Level of management review } \\
\text { result distribution }\end{array}$ \\
\hline & Documentation & $\begin{array}{l}\text { Level of availability } \\
\text { documentation in management } \\
\text { review activities }\end{array}$ \\
\hline
\end{tabular}

Gap analysis is a measurement method to know the gap between the performances of variables with certain standards. Identification of system gaps using gap analysis checklist that contains criteria or system requirements. Each criterion is rated for ease of analysis.

Gap analysis in this study using scales as discussed to LPPOM MUI as shown below;

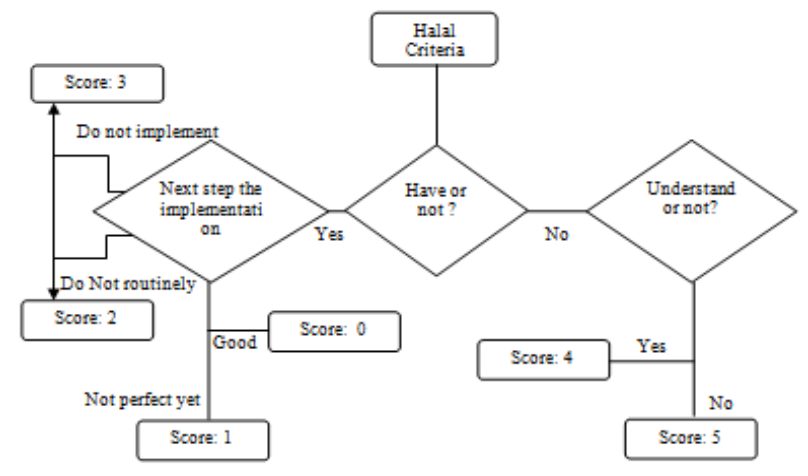

Figure 2. Gap Analysis Evaluation Flowchart

Score Description:

a. 5 : organization do not understand halal activities and do not have related documents

b. 4 : organization does not have any criteria, but understand the importance of activities

c. 3 : organization understand halal activities as a good thing but does not implement it

d. 2 : organization just do halal activities occasionally

e. 1 : organization execute halal activities, but not perfect

f. 0 : organizations execute halal activities well without any gaps 
Determination of score based on findings in document review, interview, observation and questionnaire for each parameter [21]. The scope of this research is production and logistic section within the plant site that closely related to provide halal assurance and selected outlets outside the plant to ensure product delivered to consumer provides halal guarantee. Such selected outlets are in Legoso, Pondok Ranji and Ciputat area. The duration of the study period lasted from April to October 2016.

\section{Analysis and Result}

Analysis for document conformity divided into two parts; 1) the manual and 2) implementation document. The Measurement of conformity is done by document review, and interviews on a number of responsible and related persons to HAS 23000.

The result gap are Document of Management Team $10 \%$, and total Average gap in Document $1 \%$ especially mismatch of the organizational structure compared to team position listed in the appointment letter. Conformity of the HAS 23000 implementation system can be seen from gap level compared to manual; criteria, procedures, work instructions, and the current implementation. Implementation of HAS 23000 is proved by the existence of documentations which are updated as needed especially when there are changes.

The result of gap level of manual implementation is found on the policy criteria $7 \%$, management team $40 \%$, training and education criteria $20 \%$, raw material $10 \%$, production facility $6 \%$, written procedure for critical activities $16 \%$, internal audit $7 \%$, management review $45 \%$, and not found gap in terms of area traceability and handling unsuitable product. Total average HAS implementation gap is $15 \%$.

Gaps are found in management team competencies to perform team functions and activities related to HAS 23000. The team members assumed that the related activities to provide a halal product is not a high priority. In addition, gaps also found in the material criteria in the form of non-renewal certificates of materials to ensure ingredients from suppliers. The training and education activities are held unevenly because there are still employees who have not attended the previous training. However the assessment system to check level of understanding has not been done with assuming worker are considered to have understood. The results of training and education have also been found not be documented properly. There are still workers in production and logistics departments who do not place work instructions in the work area, and less consistent in complying with work instructions.

The average percentage consistency of work instruction implementation in logistics and stockiest is $85.08 \%$, the outlet is $82.53 \%$, and consistency of implementation of work instruction in production department is $78.34 \%$

\section{References}

[1] Al Quran dan terjemahannya, Departemen Agama RI, Jakarta: Penerbit Diponegoro. 2010.

[2] Apriyantono, Anton. 2004. Teknologi dan Manajemen Halal. Bogor: IPB Press.

[3] Arikunto, Suharsimi. 2010. Prosedur Penelitian Suatu Pendekatan Praktik. Jakarta. PT Rineka Cipta.

[4] Azwar, Saifuddin. 2012. Reliabilitas dan Validitas. Yogyakarta : Pustaka Pelajar

[5] Badan Pusat Statistik. 2010. Penduduk Menurut Wilayah dan Agama yang Dianut Indonesia, dalam <sp2010.bps.go.id> diakses 9 Mei 2016.

[6] Dewi, Nancy. 2012. Halal Assurance System (HAS): The Eleven Criteria. Jakarta. $<$ http://seafast.ipb.ac.id/publication/presentation/HalalAssurance-System-The-Eleven-Criteria.pdf $>$ diunduh pada 7 Juni 2016.

[7] Direktorat Jenderal Bimbingan Masyarakat Islam, Kementerian Agama R.I. 2016.

[8] Implementasi UU No.33 Tahun 2014 Tentang Jaminan produk Halal. <perkosmi.com/wpcontent/uploads/2016/06/Materi_Kemen dag_28_Juni_2016-.pdf $>$ diunduh 1 Maret 2017

[9] Erwin, Lilly T., 2013, Yummy and Tasty-Fried Chicken. Jakarta: PT Gramedia Pustaka Utama.

[10] Faqih, Achmad. 2010. Manajemen Agribisnis. Yogyakarta :Dee Publish.

[11] Girinda, Apriyantono, dan Rimbatnya, 2003. Pedoman Produksi Halal. Jakarta:

[12] Proyek Pembinaan Pangan Halal Ditjen Bimas Islam dan Penyelenggara Haji Departemen Agama RI.

[13] Hakim, Lukmanul. 2016. Kekuatan Indonesia Dalam Menerapkan Sistem Jaminan Halal dan Tantangan Penerapan UU JPH. LPPM ITB. <www.lppm.itb.ac.id/wpcontent/uploads/2015/12/4_Lukma nul_Hakim.pptx $>$ diunduh 26 Desember 2016.

[14] LPPOM MUI. 2012. Pentingnya Sistem Jaminan Halal<https://id.scribd.com/doc/128089309/SistemJaminan-Halal-23000> diunduh 13 April 2016

[15] LPPOM MUI. 2012. Requirements of Halal Certication Policies and Procedures HAS 23000:2, $<$ http://seafast.ipb.ac.id/publication/presentation/HalalCertification-Policies-And-Procedures-Has-23000.pdf $>$ diunduh 10 September 2016.

[16] LPPOM MUI. 2015. Pelatihan Cerol-SS23000. $<$ http://www.halalmui.org/newMUI/index.php/main/detil_p age/31/1608>diakses 10 September 2016

[17] LPPOM MUI. 2012. Surat keputusan LPPOM MUI Tentang Peraturan Sistem Sertifikasi Halal Melalui Certification Online (CEROL - SS 23000) Nomor : SK39Dir/LPPOM MUUV/12 ditetapkan pada 11 Mei 2012.

[18] LPPOM MUI. 2016. TOR Pelatihan Sistem Jaminan Halal LPPOM MUI, <halalmui.orgImagesStoriesPdffTORPELATIHAN-SJH.pdf $>$ diakses 1 Oktober 2016.

[19] Mashudi. 2015. Konstruksi Hukum \& Respons Masyarakat Terhadap Sertifikasi Produks Halal. Yogyakarta: Pustaka Belajar.

[20] Mastuhu, 1995. Makanan Indonesia dalam Pandangan Islam. Jakarta: Kantor Menteri Negara Urusan Pangan Republik Indonesia.

[21] Moeloeng, Lexy J. 1998. Metode Penelitian Kualitatif. Bandung: PT Remaja Rosdakarya.

[22] Muchtadi, Tien R., 2010. Teknologi Proses Pengolahan Pangan. Bogor: IPB Press.

[23] Riaz, Mian dan Chaudhry, Muhammad. 2004. Halal Food Production. United States Of America, CRC Press dari<file:///C:/Users/610788/Downloads/Halal Food Prod uction.pdf >diunduh 28 Maret 2016. 
[24] Sanusi, Anwar. 2011. Metodologi Penelitian Bisnis: Jakarta. Salemba Empat.

[25] Sayekti, Nidya W. 2014. Jaminan Produk Halal dalam perspektif Kelembagaan. Jakarta. P3DI Bidang Ekonomi \& Kebijakan Publik. [Jurnal].

[26] Setiawan, Iwan. 2012. Agribisnis Kreatif Pilar Wirausaha Masa Depan, Kekuatan Dunia Baru Menuju Kemakmuran Hijau. Jakarta: Penebar Swadaya. 